Зима І. Я., к.м.н. (Національний університет водного господарства та природокористування, м. Рівне)

\title{
ФОРМУВАННЯ ОСНОВ ДЕРЖАВНОГО УПРАВЛІННЯ ОХОРОНОЮ ЗДОРОВ'Я ЄВРОПЕЙСЬКОЇ ЦИВІЛІЗАЦІЇ: ЕВОЛЮЦІЙНИЙ АСПЕКТ
}

У статті подано наукові основи дослідження процесу становлення централізації та державного управління в сфері охорони здоров'я, які стали основою сучасної медичної сфери в країнах Європи та в країнах, які розвивали свої соціально-економічні системи на європейських цінностях. Визначено як основу європейської системи охорони здоров'я організацію медицини в прадавніх країнах Месопотамії, Єгипті, Греції, Римі та Китаї.

Ключові слова: дослідження, становлення, система, охорони, здоров'я, прадавні країни, європейські, цінності.

Постановка проблеми. Теоретичне осмислення процесу трансформації системи охорони здоров'я, який проходить в Україні, інтеграція системи охорони здоров'я в світове інституційне середовище i необхідність управлінських інновацій в механізмі державного управління, вимагають від нас проведення глибоких теоретичних наукових досліджень в цьому напрямку. Ці дослідження допоможе комплексно оцінити стратегічні орієнтири реформування системи охорони здоров'я і зіставити перебіг сучасних процесів з великою ретроспективою становлення державного управління системою охорони здоров'я в еволюційному аспекті.

Тісний інтеграційний зв'язок даного дослідження із загальною історією, окремими аспектами економічної історії, історією державного управління вимагає по-перше, достовірного і досить глибокого висвітлення історичного фону, на якому розвивалися медичні знання і медична діяльність на окремих етапах історії в окремих регіонах світу; по-друге - неминуче б привела до вирішення принципового питання про історичне коріння і попередніх моделях розвитку охорони здоров'я. Такі дослідження дуже важливі для забезпечення об'єктивності оцінки пропонованих механізмів державного управління медициною. Прийнятий в цій частині роботи науковий метод еволюційного аналізу дозволить встановити якість реформ, які пропонуються сьогодні системі державного управління охороною здоров'я.

Аналіз досліджень і публікацій. Сучасний етап становлення системи державного управління було розкрито в монографіях таких 
відомих фахівців з цих питань як Баєва О.В. [11; 12], Білинська М.М. [12], Грігус І.М. [9], Жаліло Л.І. [12], Солоненко І.М. [12], Солоненко Н.Д. [10]. В працях цих дослідників докладно розкрито процес становлення окремих елементів системи державного управління охороною здоров'я, вдосконалення механізмів державного управління медициною, реформи сучасного етапу системи охорони здоров'я та загальні відомості про становлення сучасних методів лікування та методів управління медициною.

Невирішені раніше частини загальної проблеми. Разом з тим, вітчизняні науковці практично не досліджували еволюційні аспекти формування механізмів державного управління в класичному історичному аспекті. Ми вважаємо, що ретроспективний огляд історичних витоків формування системи державного управління охороною здоров'я Європи $€$ важливим фоном для виявлення ґрунтовних теоретичних передумов функціонування механізмів державного управління Європи та механізмів державного управління в Україні. Україна прикладає величезні зусилля для імплементації європейських підходів в практичну діяльність органів державного управління. 3 метою дослідження цих питань нами було опрацьовано значний масив історичної літератури та літератури з історії медицини авторів, які у різні роки проводили свої дослідження, серед них: Сорокіна Т.С. [1], Пригова Н.М. [2], Чехаков В.И. [3], Саидов Н.С. [4], Янь Ює [5], Лазаренко В.Г [7]. та ін.

Постановка завдання. Відповідно до заявлених положень конкретною метою даного дослідження $€$ виявлення перших ознак, елементів, складових процесу централізації медицини, державного регулювання процесом лікування, інституалізації управління медициною як соціального явища і наведення конкретних прикладів управління державою сферою медицини. Таке виявлення проводиться на прикладах стародавніх цивілізацій та окремих країн стародавнього світу.

Основні результати дослідження. Застосовуючи Закон нерівномірності економічного розвитку і виходячи з того, що кожний історичний період визначає суспільно-економічна формація, яка неминуче накладає відбиток на економічний, політичний і культурний розвиток тих періодів, які розвиваються в умовах менш прогресивної (попередньої суспільно-економічної формації, ми визначили три положення:

1. Вивчення історії управління та організації медицини може вестися в період конкретної суспільно-економічної формації (первісної, рабовласницької, феодальної та т.і.) може вестися тільки в рам- 
ках однієї окремо взятої країни або групи країн, що знаходяться на одному щаблі політичного і соціально-економічного розвитку;

2. У світовому масштабі таке вивчення історії організації медицини нездійсненно і має вестися в рамках науково прийнятого поділу всесвітньо-історичного процесу на п'ять періодів;

3. Вивчення історії організації медицини окремої країни не можна вести без врахування впливу на неї певної суспільноекономічної формації, у відриві від досягнень світової науки і культури [1].

Найбільш відомими древніми цивілізаціями, які вплинули на загально цивілізаційні процеси були за загальним переконанням стародавні держави Месопотаміі, Древній Єгипет, Індія, Китай, Греція, Рим, цивілізації Центральної і Південної Америки. Разом з тим, до стародавніх держав, які вплинули на формування європейської системи державного управління необхідно віднести Стародавню Грецію і Стародавній Рим. У свою чергу, розглядаючи сферу становлення системи державного управління медициною, $є$ доцільним розглянути не тільки систему Стародавньої Греції та Риму, але також і Єгипет і держави Месопотаміі. Це пов'язано з великим взаємним впливом, які відчували ці держави, що знаходяться в Старому Світі і які існували на невеликий географічній відстані в сфері вдосконалення прийомів лікування і організації медицини. Доцільним також $\epsilon$ аналіз досвіду Китаю, організація медицини і народні прийоми лікування якого використовуються сьогодні фахівцями і організаторами медицини всього світу.

Однією з перших відомих сучасній науці древніх цивілізацій була цивілізація Шумерів. Клинописний документ, який датується кінцем III тис. До нашої ери містить 15 прописів лікарських засобів. У ньому немає заклинань, заговорів, згадок про богів або демонів. Пізніші документи на цій території - у Вавилоні і Ассирії (XVII-XII ст. до н.е.) підтверджують, що система знань шумерів, вавилонян, ассирійців та інших народів стародавньої Месопотамії визначалася перш за все практичною необхідністю, що в повній мірі відноситься і до цілительства. Формою розвитку лікувальної справи в Месопотамії слід визнати наявність даних про існування вже в II тис. до н.е. приміщень для хворих (лікарень) при храмах, лікування в яких було емпіричним.

Передача медичних знань здійснювалася в вузькому колу посвячених. Учні лікарів навчалися в традиційній світській школі Вавилона. Про спеціальні лікарські школи в клинописних текстах не згадується [1].

Одним з найдавніших законодавчих актів минулого вважається 
базальтовий стовп з нанесеними на ньому текстами законів царя Хаммурапі (XVIII ст. до н. е.). Серед іншого на цьому стовпі є закони про заохочення і покарання лікарів за результати лікування. Слід зазначити, що при оцінці медичної допомоги враховувалося матеріальне становище пацієнтів: за одну і ту ж медичну допомогу багатий пацієнт платив в кілька разів більше, ніж бідний. І навпаки, в разі невдалого лікування багатого пацієнта покарання лікаря було більш суворим - при невдалому лікуванні раба з лікаря стягували грошовий штраф, а в разі невдалого лікування багатого відсікали руку [8].

Тексти, що дійшли до нас, які описують лікування в Древньому Єгипті датуються II тис. до н.е. У них наведені відомості про теоретичні погляди стародавніх єгиптян, уявленнях про причини хвороб і їх попередження, традиційних встановлених гігієнічних вимогах. Використання лікарських засобів в Стародавньому Єгипті було одним 3 найбільших в історії рабовласницьких цивілізацій.

Єгиптяни розуміли, що хворобу можна лікувати фармацевтичними препаратами, визнавали лікувальний потенціал масажу і ароматерапії, надавали важливого значення чистоті при лікуванні пацієнтів.

У Стародавньому Єгипті смертність після медичних процедур була, ймовірно, менше, ніж в будь-якій європейській лікарні в християнську еру, оскільки вони дуже високо цінували чистоту [6].

3 VIII ст. до н.е. в Єгипті стали з'являтися грецькі поселення. На той час мистецтву лікування навчалися в загальних школах переписувачів при храмах і вищих школах переписувачів в великих містах, де навчали ієрогліфічної писемності, каліграфії, стилістиці, математиці, астрономії, лікуванню, архітектурі, ліпленню, таємницям культових обрядів. Про існування спеціальних лікарських шкіл в царський період Стародавнього Єгипту достовірних даних немає. Розвиток торговельних і культурних зв'язків єгиптян з греками призвів до широкого поширення єгипетського лікування в античному світі [6].

В найбільш цілісному вигляді до наших часів збереглася система організації медицини та методи лікування у Китаї. Посилаючись на матеріали В.Г. Лазаренко, можна стверджувати, що в Стародавньому Китаї начало процесу централізації управління медициною відноситься до першої половині III тис. до н.е., коли правили легендарні царі Фу-сі, Шень-нун і Хуанді. Саме вони внесли вирішальний внесок у цивілізаційні процеси, в тому числі, з'явилися основоположниками традиційної китайської медицини. Починаючи з цієї епохи і по початку нашої ери, можна виділити на підставі матеріалів В.Г. Лазаренко наступні ознаки впливу державної влади на розвиток медици- 
ни:

- китайських лікарів зобов'язували вести роботу, яку зараз назвали б «дослідницькою» і доповідати про їі результати імператоpy;

- формування централізованої системи управління лікарями;

- рівень медицини дозволяв перейти до спеціалізації лікарів. У сьогоднішній системі координат ми б виділили в стародавній китайській медицині таких лікарів як: дієтологи, терапевти, дерматологи, хірурги, ветеринари;

- на підставі висновків про діяльність лікарів визначалася їх оплата за рік. Така система атестації лікарів, якій 2500 років була безпрецедентною для всього світу того часу;

- організацію допомоги хворим не з привілейованих верств суспільства можна характеризувати сьогодні як амбулаторну;

- влада заохочувала впровадження в практику діяльності всіх лікарів передових на той час методів лікування;

- систематизація знань шляхом збору у населення рецептів і способів лікування (II-І століття нашої ери було систематизовано в каталогах 10 тисяч лікарських рецептів народної медицини);

- II-І століття нашої ери була створена система громадського фінансування лікарської діяльності, організована мережа державних лікарень [7, С. 58-60].

В історії Стародавнього Китаю існувала розвинена система цілительства і нетрадиційних прийомів лікування (пульсова діагностика, голковколювання, гімнастика, припікання і т.і.). основні положення традиційної китайської медицини сформувалися в боротьбі стихійного матеріалістичного напрямку з конфуціанством і даосизмом. Одним з відомих філософів-лікарів був Ван Чун (27-97), який розвивав вчення про «зернисту» (атомистістичну) будову всіх речей.

На відміну від усталеної думки про те, що всі досягнення китайської медицини сягають корінням в далеке минуле, наші дослідження дозволили встановити, що на думку багатьох авторів вони більше розвивалися в період середньовіччя. В цей час в організації та управлінні медициною в Китаї пройшли важливі зміни. В цей період в Китаї з'явилися спеціальні лікарські школи. Такі школи були державними (імператорскими) і університетськими. Органом державного управління була Головна медична палата, (в державі Цинь XII століття). У VII столітті були видані перші ілюстровані підручники для лікувальних шкіл, атласи та бронзові фігури людей для навчання [5].

Система управління медициною в Стародавній Греції послідовно розвивалася протягом трьох тисячоліть. Рівень розвитку медици- 
ни, досконалість наукових концепцій лікарів, фінансування медицини з боку міст-полісів дозволяє зробити висновок про створення в Греції повноцінної системи управління медициною. Ця система була розпорошеною. Вона мала великі відмінності в організації в залежності від географічного положення поліса і домінування наукової медичної школи. У Греції були створені такі лікарські школи як сицилійська, книдская, кротонська, косская і ін.

У давньогрецьких містах-державах діяльність лікарів регламентувалася. У законах Лікурга (Спарта) говориться про регламентацію роботи лікарів: наприклад, спеціальні чиновники-ефори повинні були відбирати здорових немовлят, а хворих вбивати. Ці чиновники також строго стежили за дотриманням гігієнічних правил, встановлених в Спарті, в процесі підготовки воїнів [8].

Аналіз відомостей про лікування класичного періоду історії Греції показує, що його досягнення не зводяться тільки до імені Гіппократа - як це часто робиться вченими - формування численних, різних за напрямками лікарських шкіл, рівновеликих за своїми досягненнями, розуміння єдності людського організму про довкілля і пов'язаний з цим природничо-науковий погляд на причини хвороб, розвиток методів обстеження і лікування хворого були результатами виділення лікування як соціального інституту, розуміння важності лікувальної справи демократичними органами управління в полісах.

Історія лікування в Древньому Римі стала базою для створення системи охорони здоров'я сучасного типу. Символом процесу посилення державного управління медициною в Римі і проявом турботи держави про громадську охорону здоров'я стала побудована в VI столітті до н.е. Cloaca Maxima. Клоака була частиною древньої системи каналізації, за переказами, розпочатої при Тарквіній Стародавньому і закінченою Тарквінієм Гордим. План системи був створений етруськими інженерами, земляні роботи здійснювалися бідними римлянами на примусовій основі. Спочатку Cloaca Maxima служила для осушення низини між пагорбами Капітолій і Палатин, де пізніше виник римський форум; будучи відкритим каналом, вона мала близько 3 м в ширину і більше 4 в глибину. Пізніше римляни перетворили Клоаку в підземний канал. При Агриппе в 33 р до н.е. вона була перекрита кам'яними склепіннями, облицьована каменем і стала використовуватися для видалення з міста в Тибр нечистот і дощових стоків. Cloaca Maxima збереглася до теперішнього часу і використовується як зливова каналізація [14]. Будівництво цієї споруди знаменувало перехід від храмової і ініціативної системи лікування і розвитку медицини до державної системи охорони здоров'я. Незважаючи на 
будівництво такого важливого інфраструктурного проекту для забезпечення санітарії та гігієни в Римі, розвиток безпосередньо практикуючої медицини в цей час в Римі значно відставало від Греції.

Стрімкого розвитку набуває розвиток охорони здоров'я в Римі починаючи 3 VI століття до н.е. В цей час вводиться контроль за будівництвом і експлуатацією громадських будівель і доріг, санітарним станом бань, ринків, інших громадських споруд. В цей час в Римі з'являються лікарі-іноземці (в більшості своїй Греки), спочатку як раби, а потім як вільновідпущені і вільні громадяни, розвиваються елементи державної регламентації їх діяльності.

В наслідок цього і на основі розвитку армії і армійської медицини розширилася практика будівництва військових госпіталів (валетудінаріев). Крім того, в Римі існували валетудінаріі для рабів. У Древньому Римі існували приватні і державні лікарські школи, в яких були введені посади архиатров - викладачів медицини. Таким чином, в Стародавньому Римі склалися основні елементи системи охорони здоров'я, які були запозичені пізніше в систему охорони здоров'я європейського зразка.

Законами Стародавнього Риму (Законами 12 таблиць) передбачалися заходи санітарного характеру: заборона користування водою із забрудненого джерела, контроль за харчовими продуктами на ринках, дотримання правил поховання, виконання вимог по влаштуванню громадських лазень і т. і. (За всім цим стежили спеціальні чиновники-едили). Міста зобов'язували наймати і утримувати так званих «народних лікарів», в обов'язки яких входила охорона здоров'я населення. Чітко організована медична служба була і в римській армії, причому лікарі когорт, легіонів, військових госпіталів не тільки займалися лікуванням поранених і хворих, а й стежили за санітарним станом армії, тобто виконували обов'язки з охорони здоров'я воїнів. Римські водопроводи і лазні досі свідчать про високу гігієнічної культури античності [8].

Тривалий період в історії Європи, іменований як Середньовіччя і який прийшов на зміну Стародавнього Риму відомий всім своїм застоєм в розвитку науки, культури, економіки та у справі організації, управління і розвитку медицини, а також забуттям багатьох досягнень медичної науки попередніх епох.

Автори виділяють основні характеристики санітарно-гігієнічних норм життя того часу.

- відсутність каналізаційної та водопровідної системи;

- антисанітарія вулиць середньовічного міста;

- система сухих туалетів;

- антисанітарія середньовічного будинку; 
- відсутність елементарної особистої гігієни;

- недоброякісне харчування;

- епідемії;

- дитяча смертність [13];

Специфічними і не пов'язаними історично з попередньою наукою були методи лікування середньовічної медицини. До таких методів належать:

- поклоніння «потрібним» святим;

- обереги і амулети;

- трав'яні зілля. Поняття фітотерапії, що використовується сьогодні, вельми мало було схоже на середньовічне лікування травами. Справа в тому, що в середні століття приділялася увагу не стільки самої траві, як такої, а тому, в яке свято вона була зібрана, в який саме час дня і з якими саме заклинаннями;

- кров;

- мінерали і камені;

- дані астрології [13].

Висока смертність в період епідемій змушувала держави, що б не зникнути з лиця землі, концентрувати свої сили в значній мірі не стільки на запобігання епідеміям, скільки на усунення їх наслідків і локалізацію, створюючи єдині державні структури з утилізації трупів.

Тільки в XV столітті почали проявлятися зачатки державного управління медициною: створення комунальних лікарень, створення лікарень за гроші бюргерів, формування бібліотек, реформування системи викладання медицини в університетах. Після великих географічних відкриттів, які спричинили переділ світу, військові дії медичні знання у системі державного управління були поставлені на військові рейки та почали розвиватися стрімкими темпами, починаючи з XVI століття. Розвиток систем управління охороною здоров'я в сучасну епоху призвів до формування трьох широко поширених моделей, які будуть описані нижче. До таких моделей належать: модель Бісмарка (німецька), модель Беверіджа (англійська), модель Семашка (Радянська).

Висновки. Дане дослідження заповнює певний пробіл в науці державного управління в частині еволюційного аналізу і ретроспективного дослідження становлення механізмів державного управління системою охорони здоров'я. Дані дослідження сприяють глибокої теоретичної розробки питань державного управління медициною в історичному аспекті, в різних державах на основі досягнень вітчизняної наукової методології і висувають оригінальну авторську концепцію періодизації становлення елементів державного управління та 
хронології всесвітньої історії медицини в частині її централізації і регулювання.

1. Сорокина Т. С. История медицины»: Академия, Academia; Москва; 2008. 320 с. 2. Прыгова Н. М. Медицина в ацтекском государстве : автореф. дис. ... канд. мед. наук : 07.00.10. М., 1982. 20 с. 3. Чехаков В. И. Гигиенические воззрения Ибн Сины (Авиценны) : автореф. дис. ... канд. мед. наук : 07.00.10. М., 1983. 18 с. 4. Саидов Н. С. Сопоставительный анализ учений Аристотеля и Ибн Сины о человеке : автореф. дис. ... канд. філософ. наук : 09.00.03. Душанбе, 2009. 24 с. 5. Янь Ює. Диспансерный метод в здравоохранении СССР и Китайской народной Республики : автореф. дис. ... канд. мед. наук : 07.00.10. Ленинград, 1958. 8 с. 6. История медицины. Египет. URL: https://habr.com/ru/post/403361/стория; (дата звернення: 15.05.2019). 7. Лазаренко В. Г. Государственное управление медициной в Древнем Китае. Проблемы социальной гигиены и история медицины. 2007. № 6. С. 58-60. 8. Социальная медицина. URL: https://www.google.com/search?ei=tulcxozcexirgsn456wag\&q. (дата звернення: 15.05.2019). 9. Грігус І. М. Нетрадиційні засоби оздоровлення : навч. посібник. Рівне : НУВГП, 2017. 242 с. 10. Солоненко Н. Д. Економіка охорони здоров'я. К. : ДП «Вид. дім «Персонал», 2014. 408 с. 11. Баєва О. В. Основи менеджменту охорони здоров'я. К. : МАУП, 2007. 328 с. 12. Управління підприємницькою діяльністю в галузі охорони здоров'я : кол. моногр. / О. В. Баєва, М. М. Білинська, Л. І. Жаліло та ін. ; за ред. О. В. Баєвої, І. М. Солоненка. К. : МАУП, 2007. 376 с. 13. Реформация и медицина средних веков. URL: https://r500.ua/reformatsiya-imeditsina-srednih-vekov/ (дата звернення: 15.05.2019). 14. КЛОАКА (лат. Cloaca Maxima от cluere, чистить). URL: https://w.histrf.ru/articles/article/show/k. (дата звернення: 15.05.2019).

\section{REFERENCES:}

1. Sorokina T. S. Istoriia meditsiny»: Akademiia, Academia; Moskva; 2008. 320 s. 2. Pryhova N. M. Meditsina $v$ atstekskom hosudarstve : avtoref. dis. ... kand. med. nauk : 07.00.10. M., 1982. 20 s. 3. Chekhakov V. I. Hihienicheskie vozzreniia Ibn Siny (Avitsenny) : avtoref. dis. ... kand. med. nauk : 07.00.10. M., 1983. 18 s. 4. Saidov N. S. Sopostavitelnyi analiz uchenii Aristotelia i lbn Siny o cheloveke : avtoref. dis. ... kand. filosof. nauk: 09.00.03. Dushanbe, 2009. 24 s. 5. Yan Yuie. Dispansernyi metod v zdravookhranenii SSSR i Kitaiskoi narodnoi Respubliki : avtoref. dis. ... kand. med. nauk: 07.00.10. Leninhrad, 1958. $8 \mathrm{~s}$. 6. Istoriia meditsiny. Ehipet. URL: https://habr.com/ru/post/403361/storyia; (data zvernennia: 15.05.2019). 7. Lazarenko V. H. Hosudarstvennoe upravlenie meditsinoi $\vee$ Drevnem Kitae. Problemy sotsialnoi hihieny $i$ istoriia meditsiny. 2007. № 6. S. 58-60. 8. Sotsialnaia meditsina. URL: https://www.google.com/search?ei=tulcxo-zcexirgsn456wag\&q. (data zvernennia: 15.05.2019). 9. Hrihus I. M. Netradytsiini zasoby ozdorovlennia : navch. posibnyk. Rivne : NUVHP, 2017. 242 s. 10. Solonenko N. D. Ekonomika 
okhorony zdorovia. K. : DP «Vyd. dim «Personal», 2014. 408 s. 11. Baieva 0. V. Osnovy menedzhmentu okhorony zdorovia. K. : MA-UP, 2007. 328 s. 12. Upravlinnia pidpryiemnytskoiu diialnistiu $v$ haluzi okhorony zdorovia : kol. monohr. / O. V. Baieva, M. M. Bilynska, L. I. Zhalilo ta in. ; za red. O. V. Baievoi, I. M. Solonenka. K. : MAUP, 2007. 376 s. 13. Reformatsiia i meditsina srednikh vekov. URL: https://r500.ua/reformatsiya-i-meditsina-srednih-vekov/ (data zvernennia: 15.05.2019). 14. KLOAKA (lat. Cloaca Maxima ot cluere, chystyt). URL: https://w.histrf.ru/articles/article/show/k. (data zvernennia: 15.05.2019).

Рецензент: д.е.н.. професор Левицька С. О. (НУВГП)

Zyma I. Yu., Candidate of Medical Sciences (Ph.D.) (National University of Water and Environmental Engineering, Rivne)

\section{FORMATION OF THE PUBLIC GOVERNANCE FOR HEALTH CARE OF EUROPEAN CIVILIZATION: EVOLUTION ASPECT}

It is proved that a retrospective review of the historical origins of the formation of a public health management system in Europe is an important background for identifying the sound theoretical preconditions for the functioning of the mechanisms of public administration in Europe and the mechanisms of public administration in Ukraine. Ukraine has put enormous efforts to implement European approaches to the practice of public administration.

The specific objective of this study is to identify the first signs, elements that are part of the process of centralizing medicine, state regulation of the treatment process, the institutionalization of management of medicine as a social phenomenon, and the imposition of concrete examples of state management in the field of medicine. The article fills a certain gap in the science of public administration in the part of evolutionary analysis and retrospective study of the formation of mechanisms of public administration by the health care system. The article contributes to the deep theoretical development of issues of state management of medicine in the historical aspect. She examines the management of medicine in various states on the basis of the achievements of domestic scientific methodology. The author presents the original concept of the periodization of the formation of the elements of public administration and the chronology of the world history of medicine in terms of its centralization and regulation, the formation of European values in society. 
It was determined that the historical sources that influenced the formation of the modern concept of public administration of the health care system of Europe were in the first place such ancient civilizations as the country of Mesopotamia, Egypt, Greece, Rome. General sanitary and hygiene systems, cleanliness control, appointment of state doctors, methods of their certification and payment, organization of ambulatory and hospital provision of these countries correspond to many modern approaches of social organization of medicine and mechanisms of public administration. The medical culture of China, which was formed in the 2 nd millennium BC, has evolved evolving to the present and has significantly influenced all world systems of medicine organization.

Keywords: research, formation, system, protection, health, ancient countries, European, values.

Зима И. Я., к.м.н. (Национальный университет водного хозяйства и природопользования, г. Ровно)

\section{ФОРМИРОВАНИЕ ОСНОВ ГОСУДАРСТВЕННОГО УПРАВЛЕНИЯ ОХРАНОЙ ЗДОРОВЬЯ В ЕВРОПЕЙСКОЙ ЦИВИЛИЗАЦИИ: ЭВОЛЮЦИОННЫЙ АСПЕКТ}

В статье представлены научные основы исследования процесса становления централизации и государственного управления в системе охраны здоровья, которые стали основой современной медицинской сферы в странах Европы и в странах, которые развивали свои социально-экономические системы на европейских ценностях. Определены как основа европейской системы здравоохранения организация медицины в древних странах Месопотамии, Египте, Греции, Риме и Китае.

Ключевые слова: исследование, становление, система, охраны, здоровье, древние страны, европейские, ценности. 